\title{
TÁVSZOLGÁLTATÁSOK ÉS A RÉGIÓK ESÉLYEI AZ ÚJ TERÜLETI MUNKAMEGOSZTÁSBAN - A HÍVÓKÖZPONTOK
}

\author{
(Remote Services and the Possibilities of Regions in the New \\ Spatial Division of Labour - The Call Centres)
}

RAFFAY ZOLTÁN

Kulcsszavak:

hivóközpont fejlett információs és kommunikációs technológia

A tanulmány egy egyre jelentösebb szolgáltatási ágazat, a hivóközpontok kialakulásának okait, az azt lehetôvé tevõ tényezöket és az ágazat eddigi fejlödését mutatja be, kitérve a hivóközpontok lehetséges jövőbeli fejlödési esélyeire is. A szerzô azt is vizsgálja, hogy a hivóközpontok eddigi telephelyi döntéseik során a regionális kiegyenlítödés irányába hatnak-e, avagy az erösebb gazdasági alappal rendelkezõ régiókba települnek-e, a már meglévô fejlettségbeli kuilönbségeket erõsitve.

\section{Bevezetés}

Az elmúlt években igen gyors ütemben fejlödött a hagyományos szolgáltatásoktól egy lényegi tulajdonságában eltérỏ, a szolgáltatást nyújtó és az azt igénybe vevő közötti fizikai kontaktus kényszerét megszüntető új munkaszervezési és szolgáltatási módszer, a hívóközpontok szektora. Becslések szerint 2001-re félmillió ember, a foglalkoztatottak 2,2\%-a dolgozik e szektorban, telefonos hívóközpontokban az Egyesült Királyságban. A hívóközpontok szinte minden nagyvállalat tevékenységének szerves részévé váltak az ügyfelekkel történỏ kapcsolattartásban.

Hívóközpontokat először az Amerikai Egyesült Államokban hoztak létre és ma már a világ számos országában megtalálhatók. Müködnek a bankszektorban, a biztosítási iparban, megkönnyítik az értékesítést, számlázást, az ügyfélszolgálatot; vannak direkt marketingre és vásárlói szokások kutatására szakosodott hívóközpontok; az idegenforgalomban szállásfoglalásra, jegyfoglalásra lehet felhasználni őket; számos cég müszaki és egyéb segítségnyújtásra hozott létre hívóközpontokat stb.

Mivel elvileg bárhová telepíthetők, ahol megfelelő távközlési infrastruktúra és kellő számú, megfelelöen képzett munkaerő rendelkezésre áll, így a periférikus helyzetủ területek számára lehetőséget kínálnak a területi munkamegosztásba történő intenzívebb bekapcsolódásra. A tanulmány a hívóközpontok telepítő tényezőinek vizsgálatával arra keresi a választ, hogy az ágazat eddigi fejlödése a regionális kiegyenlítődés avagy a további polarizálódás irányába hat-e. 


\section{Új távközlési technológiák, az információs társadalom megjelenése,} új területi munkamegosztás

A globalizáció a XX. század végének és századunk elejének egyik legtöbbeket foglalkoztató témája, a média mellett a tudományos élet figyelmének is egyik kitüntetett tárgya. A nemzetközi szinten integrálódó termelési és elosztási rendszerek, amiben sokan a globalizáció lényegét látják, térben egyenlötlenül megmutatkozó jelenség. Az eltérő adottságú területek különböző mértékben tudnak bekapcsolódni az információs gazdaságba, amely az új információs és kommunikációs technológiákra, a modern világ jólétének és gazdasági növekedésének fő forrására épül. Az információs és kommunikációs technologiák eltérő használata a világot „gyors” és "lassú” részre osztja (Knox 1995), amely két rész között a munkaerő alapvetően abban tér el egymástól, hogy képes-e használni az új technológiákat: vannak eszerint „techno-írástudók” és ,techno-analfabéták”.

Knox a gyors és a lassú világ fogalmát térben értelmezi, az előzöt a világgazdaság három nagy centrumával, az utóbbit pedig a világ többi részével, a globális perifériával azonosítva, míg Hoogvelt (1997) szerint a választóvonal inkább társadalmi, mint térbeli, mindkét világ elemei megtalálhatók a világ minden régiójában.

A gyors világot mindazonáltal elsösorban Észak-Amerika, Nyugat-Európa és Japán, illetve néhány újonnan iparosodó ország képviseli, amelyek jelentős beruházásokat hajtottak végre a modern informatika és a hozzá kapcsolódó oktatási infrastruktúra terén. A lassú világot föleg a globális periféria kevésbé fejlett országai alkotják, amelyek egyre inkább peremhelyzetbe kényszerülnek - korábban kizsákmányolt, ma mellözött térségei a világnak.

A világ városai közötti információ-, szolgáltatás-, áru- és pénzáramlás, illetve a személyek egyre nagyobb mértékü mozgása a korábban alapvetően nemzeti szintủ városhálózatokat egyre inkább globális városhálózattá formálja át. A transznacionális városhálózatot kis számú világváros avagy globális város vezeti, itt találhatók a transznacionális vállalatok központjai, a fejlett pénzügyi és üzleti szolgáltatások és a távközlési infrastruktúrák legnagyobb koncentrációi. Minden jelentősebb város igyekszik azonban nemzetközi orientációját erösíteni, akár úgy, hogy egy jövedelmezö piaci rést vagy piaci fülkét igyekszik találni, ahol vezető szerepre tehet szert. Példa erre Szingapúr, amely a délkelet-ázsiai multinacionális vállalatok központjainak ad otthont; Miami, amely az Egyesült Államok és Latin-Amerika közötti kereskedelmi és befektetési ügyleteket felügyeli; vagy Luxemburg, amely Európa legnagyobb „offshore” pénzügyi szolgáltató központjává nötte ki magát.

Mivel ezek a városok csak korlátozott gazdasági szereppel és/vagy területi hatókörrel rendelkeznek, szerencsésebb transznacionális, mintsem globális városnak nevezni őket. Az informatika növekvő szerepe müködésük során a városi vonzáskörzetek hagyományos koncepcióját egyre inkább értelmetlenné teszi. Ugyanígy egyre kevésbé van értelme a nemzetközi városrendszer hierarchiájáról beszélni, mivel a globális hálózatokon belül a vállalatok rugalmassága és az új távközlési technológiák az ,alsóbbrendü” városok helyzetét gyorsan képesek megváltoztatni. 
Távszolgáltatások és a régiók esélyei az új területi munkamegosztásban - a hívóközpontok. Tér és Társadalom, 15. 2001. 3-4. 207-230. p.

TÉT XV. évf. 2001 - 3-4

Kitekintö

209

Az információs és kommunikációs technológiáknak a gazdaság szervezeti és térbeli átrendezödésében játszott szerepével egyre több kutatás foglalkozik (Richardson 1994; Grimes 1999; Breathnach 2000 stb.). Ugyanakkor sokkal kevesebb figyelmet szentel a tudományos világ azoknak a szervezeti és térbeli vâltozásoknak, amelyek abból adódnak, hogy számos cég az informatikai eszközök, elsősorban a telefon-hálózatok segítségével igyekszik szolgáltatásait eljuttatni ügyfeleihez. Az ügyfélszolgálatot eddig olyan tevékenységnek tekintették, amely telephelyválasztásában meglehetösen korlátozott, az ügyfél fizikai közelségét igényli. Hagyományosan ez a felfogás igaz is volt és számos tevékenység esetében még ma is megállja a helyét, több ügyfélszolgálati funkció esetében azonban a piacokhoz viszonyított közelség már nem kulcsfontosságú telepítő tényező:

- az irodatechnika új fejlesztéseinek felhasználásával számos, különböző területen müködő cég képes költséghatékony módon ügyfélszolgálatát ellátni telefonon keresztül;

- az ügyfelekkel történő kapcsolattartás megváltozása kihat a vállalkozások szerveződésére is, és gyakran oda vezet, hogy a cégek ügyfélszolgálati irodai funkcióikat a „hátsó irodák” második generációjába telepítik át;

- ugyanazok a technológiák, amelyek az ügyfélszolgálat átszervezését lehetỏvé teszik a telefon-alapú szolgáltatásokat nyújtó cégek telephely-választásában is nagyfokú szabadságot biztosítanak.

A „hátsó iroda” kifejezés magyarázatra szorul. A hátsó irodákat (back offices) eredetileg azért hozták létre, hogy csökkentsék azoknak a vállalati belső szolgáltatásoknak a költségeit, amelyek kevés személyes kontaktust igényeltek akár a vállalatokon belül, akár a külvilág felé. A szabványosított, gyakran igénybe vett feladatok koncentrációja a hátsó irodákba (a méretgazdaságosság és a specializáció jegyében) az 1950-es évek végén az Egyesült Államokban kezdődött el, az irodai munka számítógépesítésének elterjedésével. Azóta számos vállalati funkciót (könyvelés, bérszámfejtés, számlázás, hitelkártya-adatok feldolgozása, bizonyos müszaki és kutatási tevékenységek) telepítettek át a hátsó irodákba. Ezeknek a funkcióknak a koncentrációjához azokra a technológiákra volt szükség, amelyek segítségével a munkafolyamatot különösebb szakértelmet nem igénylö, rutinjellegủ részfeladatokra lehetett bontani. A technológia fejlődésével ezeket a munkafolyamatokat a fö üzleti tevékenységtöl távol, gyakorlatilag bárhová lehetett telepíteni, ugyanakkor a termelés folyamatával és a központtal való kapcsolat megmaradt. (A belsỏ vállalati szolgáltatások taylori elveket követő átszervezése ma is folyik például a bankszektorban.)

A hátsó irodák második hulláma, amellyel a tanulmány foglalkozik, annyiban tér el az első hullámtól, hogy itt nem belső, vállalaton belüli szolgáltatások áttelepítéséről van szó, hanem az ügyfélszolgálat új, speciálisan kialakított módszeréről - az ügyfélszolgálatnak az „előtérböl” a „háttérbe” helyezéséről (a szó fizikai értelmében, nem a jelentőségét tekintve).

Az új típusú hátsó irodák alapvetően különböznek a hagyományos hátsó irodáktól a bennük folyó tevékenységek, a munkaerővel szemben támasztott követelmények 
és a vállalati szerveződés miatt. A munka egyes fázisainak a hátsó irodák első generációjába való koncentrálása bizonyos térbeli következményekkel járt, számos irodát külvárosokba vagy kevés alternatív munkahelyet nyújtó területre telepítettek, ahol olcsó, többnyire női munkaerő végezte az alacsonyan fizetett, rutinszerủ munkát. A hátsó irodák második hulláma azonban megváltoztathatja a vállalatok térbeli szerveződését - a tanulmány ennek a mikéntjére keresi a választ.

\section{A hívóközpontok megjelenése és fejlödése}

A hívóközpontok a szakirodalomban egyre nagyobb figyelmet kaptak az elmúlt évek során (Richardson-Marshall 1996; Bain-Taylor 1999; 2000; Breathnach 2000; Bristow-Munday-Gripaios 2000; Richardson-Belt-Marshall 2000 stb.). A hívóközpontok először a pénzügyi szektorban jelentek meg, a városközpontokban található bankfiókok bezárásával párhuzamosan, de ma már számos tevékenységre szakosodnak az utazási iparágtól kezdve a távközlésen át a személygépkocsiértékesítésig és a postai megrendelésekig, illetve a közmũvekig, de kormányzatok és önkormányzatok is felismerték már a bennük rejlő lehetöségeket.

A távközlési költségek csökkenése, a müszaki fejlödés, a telefónia szélesebb körü elterjedése következtében egyre több cég igyekszik müködésének hatékonyságát az információs és távközlési technológiák nyújtotta lehetőségek kihasználásával javítani. A munkaerő-intenzív értékesítési, marketing és segítségnyújtási szolgáltatásokat egyre gyakrabban a mára már kiforrott technológiának számító telefonon keresztül kínálják. A távszolgáltatásoknak a gazdaság több szektorára való kiterjedésével a vállalatok hasznosítani tudják meglévő fogyasztói adatbázisaikat, a távközlés funkcionalitásának javulása pedig meggyorsítja a telefonhívások forgalmát, lehetővé téve nagyobb távszolgáltató vállalkozások kialakulását és ezáltal a termelékenység és a munka intenzitásának növelését (Bristow-Munday-Gripaios 2000).

A vállalatok elsősorban azért alkalmazzák a fejlett információs és kommunikációs technológiákat, hogy az egyre élesebb versenyhelyzetben növeljék eladásaikat, termelékenységüket, illetve csökkentsék költségeiket. Azokban az ágazatokban, ahol a szolgáltatások hasonlóak (ilyen például a bankszektor), erösebb a verseny és így a késztetés is a fenti technológiák bevezetésére. A versenynyomás és az erre adott válaszként kifejlesztett új technológiák számos olyan munkakört hoztak létre, amelyek földrajzi értelemben mobilak, megszünt több szolgáltatás esetében az a kényszer, hogy a fogyasztókhoz és a vállalat többi dolgozójához közel helyezkedjenek el.

A vállalatok szervezeti változásai kétféleképpen ösztönözhetik a hívóközpontok létrejöttét: egyrészt a vállalatok hátsó irodai avagy rutinszerủen végezhetö funkcióikat decentralizálhatják a vállalatközponttól távol elhelyezkedő telephelyekre, másrészt a vállalat nem alapvető tevékenységeinek elvégzését a cégen kívüli alvállalkozókra bízhatják. llyen, gyakran külső alvállalkozóknak leadott tevékenységek az ügyfélszolgálati vagy marketingtevékenység, amelyek gyakran szezonálisan vagy 
Távszolgáltatások és a régiók esélyei az új területi munkamegosztásban - a hívóközpontok. Tér és Társadalom, 15. 2001. 3-4. 207-230. p.

TÉT XV. évf. 2001 - 3-4

Kitekintö

211

kampányszerüen jelentkeznek (például új termék vagy szolgáltatás bevezetését követően), és amelyek intézése rugalmasságot és különleges szakértelmet igényel.

A gyakorlat azt mutatja, hogy a vállalkozások többnyire az első megoldást részesítik előnyben: például az Egyesuilt Királyság összes hívóközpontjának mintegy 90\%-a vállalaton belüli egység, amely a központtól távolabb elhelyezkedve nyújt rutinszerüen végezhető uigyfélszolgálati tevékenységet.

A hívóközpontok telephely-választásuknál egyszerre törekednek a vállalati tevékenységek racionalizálására és keresnek olyan új helyeket, amelyek a lehetö legkisebb kockázatot hordozzák és a lehető legalacsonyabb költségvonzattal járnak. A költségcsökkentés érdekében tömöruilnek a távszolgáltatások hívóközpontokba: az ingatlanokkal kapcsolatos költségek a vállalatok tulajdonában lévő ingatlanok racionálisabb kihasználásával, a tőke és a munkaerő költségei pedig a technológia intenzívebb használatával és a munkaerő egy telephelyre történő összevonásával csökkenthetök. A kockázat minimális szintre történő csökkentésének igénye azonban korlátozza a hívóközpontok telephely-választását régiókon belül és azok között is. Marshall és Richardson (1996) megfigyelései szerint, ahol a cégeket történelmi tényezők befolyásolják (mint például már kialakult ingatlanstruktúra és a vállalati központhoz való közelség igénye), a telefonos tevékenységeket szívesen telepítik a meglévő egységek közelében elhelyezkedő alacsony költségủ területekre vagy felújított városközpontokba. Egy 1997-es hívóközpont-felmérés eredménye azt mutatta (Grimley International Property Advisers 1997, idézi Bristow-Munday-Gripaios 2000), hogy az új központok 75\%-a már müködỏ vállalati egységek közelébe települt.

Ahol ilyen megkötések nem korlátozzák a telephely-választást, a hívóközpontok valóban szabadon mozgatható egységek, amelyek telephely-választását csak a megfelelő mennyiségủ és minőségü munkaerő, az alkalmas telekommunikációs infrastruktúra, az irodahelyiségek és üzemegységek, valamint a közlekedési infrastruktúra megléte vagy közelsége befolyásolja. A fejlett távközlési infrastruktúra talán a legkevésbé korlátozó telepítő tényező, legalábbis a nyugat-európai országokban, ahol néhány rurális térséget leszámítva mindenhol megfelelö minőségben rendelkezésre áll. Az irodai és u̇zemegységek számára azok a területek tủnnek legelőnyösebbnek, amelyek nagyobb városok közelében helyezkednek el vagy olyan üzleti parkok mellett, amelyek nagy alapterületủ helyet és alacsony bérleti díjakat tudnak kínálni. A telephely-választás e rugalmassága előnyös helyzetbe hozhatja a periférikus jellegü régiókat, ahol az alacsonyabib bérleti díjak és a nagyobb területú helyiségek, illetve a sok urbánus területre jellemző túlzsúfoltság hiánya kellemes, vonzó környezetet biztosíthat a hívóközpontok tulajdonosai számára. Egyes szerzők (Richardson-Gillespie 1996) szerint a tőkejuttatások, ösztönzések és a múködés során nyújtott különböző támogatások is fontos szerepet játszhatnak a végső telephely-választási döntésben a kezdeti infrastrukturális beruházási költségek csökkentése révén.

A hívóközpontok munkaerö-intenzív egységek: a munkaerővel kapcsolatos költségek a hívóközpontok összes költségének átlagosan több, mint 58\%-át teszik ki. Mivel a legtöbb hívóközpont naponta legalább 12 órában múködik (de nem ritka az 
ennél hosszabb, akár napi 24 órás munkaidő sem), meglehetősen nagy munkaeröbázisra van szükség ahhoz, hogy a normál munkaidön kívüli órákban is müködhessen a hívóközpont, anélkül, hogy túlóradíjat kellene fizetni. A hívóközpontok telephely-választásuk során ezért a nagy számban rendelkezésre álló képzett, rugalmas és alacsony költségű munkaerőt keresik, ami a korábbi ipari régiókat (az Egyesült Királyságban például Skóciát vagy az északkelet-angliai régiót) különösen vonzóvá teszi: ezek azok a területek, ahol elegendỏ számban rendelkezésre áll olcsó és viszonylag jól képzett munkaerő a korábbi női irodai alkalmazottakból.

A megfelelő mennyiségü és minőségủ munkaerő iránti igényből következik, hogy a hívóközpontok telephely-választására hatással van a területi munkamegosztás jelenlegi szerkezete, ugyanakkor a hívóközpontok képesek befolyásolni annak jövőbeli alakulását. A periférikus régiók telephelyeik vonzerejét intézményi bázisuk fejlesztésével növelhetik: Dublin például nemzetközi pénzügyi szolgáltatási központot hozott létre az alacsony társasági nyereségadóra és az olcsó munkaerőre mint vonzerőkre építve. A központ a remények szerint nagy, megfelelöen képzett munkaerö-bázist fog létrehozni, amely erősíti majd vonzerejét és további vállalkozásokat vonz. Meg kell azonban találni a megfelelö egyensúlyt az alkalmas munkaerövel rendelkező területeken a klaszteresedés nyújtotta előnyök és a munkaerő magas fluktuációja és költségei között: a hívóközpontok klaszterei lehetőséget adnak az alkalmazottaknak, hogy kihasználják a magasan képzett munkaerő iránti igényt és felnyomják a munkabéreket a régióban, megváltoztatva annak a munkaerő-piaci jellemzőit.

Összefoglalva, a hívóközpontok terjedésének háttere a vállalati struktúrák szervezeti és térbeli változásaiban keresendő. $\mathrm{E}$ változások a technológia intenzívebb és hatékonyabb használatának, a piaci viszonyokra és a fogyasztói igényekre való rugalmasabb reagálásnak a követelményére adott válaszok. Ez a nyomás a gazdaság számos ágazatában érzékelhető, de különösen erős a pénzügyi szektorban, ahol a szolgáltatások erősen hasonlítanak egymáshoz. A technológia fejlődése lehetővé teszi, hogy távolabbról irányítsák és ellenỏrizzék a hátsó irodai funkciókat. Ennek révén a költségcsökkentések és a méretgazdaságosság lehetőségével együtt a periférikus régiók potenciálisan vonzóvá válnak a hívóközpontok telephely-választási döntései során. A kockázat minimalizálásának és a költségelőnyök maximalizálásának igénye, illetve a munkaerő kialakult térbeli eloszlása ugyanakkor a már müködő vállalati egységek vagy alvállalkozók közelében levő telephelyeknek mint a hívóközpontok lehetséges telephelyeinek vonzerejét növelik.

A legtöbb vállalkozás alkalmaz olyan dolgozókat, akik feladata hívások fogadása és továbbítása, ebben az értelemben gyakorlatilag minden szervezetnek van „hívóközpontja". A fogalom ezért mindenképpen szükítésre szorul. A hívóközpontok egy elfogadott definíciója a következö: „Egy szervezeten belül található olyan elkülönülö üzleti egység, ahol legalább 20 ember dolgozik, akiknek a feladata elöre meghatározott és mérhetö célkitúzések szerint telefonhívások kezdeményezése vagy fogadása, az ügyfélszolgálat, a könyvelés, a számlázással kapcsolatos információszolgáltatás, a múszaki segítségnyújtás vagy a telemarketing területén. A hívóköz- 
pont müködése során általában fejlett informatikai és távközlési hardvereket és szoftvereket használ (pl. automatikus hívástovábbítás, számítógépesített telefonrendszer, grafikus interface." (Mitial Group 1997 - idézi Bain-Taylor 1999)

A hívóközpontok terjedése a regionális és helyi gazdaságok számára több vélt vagy valós előnyt jelenthet. E központok alapvetően új munkalehetőségeket nyújtanak, munkahelyeket teremtenek, fö- és mellékállásúakat egyaránt, gyakran munkanélküliséggel sújtott vagy csak szezonális munkalehetőségeket kínáló területeken. A hívóközpontok exportorientált természete miatt a központokat sikeresen vonzani képes régiók fizetési mérlege javulhat. A hívóközpontok lehetỏvé teszik a régión belül már adott képességek mobilizálását és új képességek kifejlesztését, amelyek később más típusú vállalkozások számára is hasznosak lehetnek. Emellett nagy figyelmet fordítanak az alkalmazottak képzésére és termékismeretük javítására, elsősorban az informatikai szektorban, ezzel a régión belüli ismereteket és képességeket gyarapítják.

A hívóközpontok hátrányaiként megemlíthető, hogy az általuk létrehozott munkahelyek gyakran alacsony képzettséget igénylő, alacsony színvonalú munkát biztosítanak, és sokkal kevesebb magasan képzett szakember számára adnak munkát. Nem tudjuk ma még azt sem, hogy a hívóközpontoknak mi lesz a hosszú távú hatása a regionális gazdaságra, létrejön-e spin-off e központokból (Bristow-MundayGripaios 2000). Fennáll annak a veszélye is, hogy a fejlett telekommunikációs technológiák további fejlödésével vagy szélesebb körü elterjedésével a technika átveszi a hívóközpontok alkalmazottainak szerepét, akiknek (vagy legalábbis egy jelentős részüknek) a munkája így feleslegessé válik (például az Internet használatának további terjedésével csökken a hívóközpontok iránti igény stb.)

Az eddigi tapasztalatok alapján a hívóközpontok elhelyezkedése, és így a fent vázolt elönyök és veszélyek térben nem egyenletesen jelentkeznek. Bár a hívóközpontok elvileg bárhová telepíthetők (az angol nyelvủ szakirodalom a ,footloose”, szabadon mozgatható kifejezéssel jellemzi öket), a megfelelö képzettséggel rendelkezö munkaerő és a különböző régiók ágazati és foglalkoztatotti szerkezetében mutatkozó különbségek korlátozzák ezt a szabad mozgást. A hívóközpont-szektor növekedésének elsődleges oka, függetlenül attól, hogy a hátsó irodai szolgáltatások racionalizálása jegyében vagy teljesen új vállalkozásként hozzák létre azokat, a vállalatok törekvése a költségcsökkentéssel elérhető versenyképességre. Így hiába teszi a technológia fejlödése szinte teljesen mobillá a hívóközpontokat, bizonyos területek sokkal vonzóbbak maradnak számukra, mint mások. A hívóközpontok telephelyválasztását és párhuzamosan a regionális gazdaságokban új munkahelyek teremtését erősen korlátozzák a területi munkamegosztás kialakult egyenlötlenségei, és az eddigi tapasztalatok szerint a hívóközpontok inkább erösítik a szolgáltató tevékenységek már meglévő koncentrációit, mintsem a regionális kiegyenlítődést szolgálnák. 


\section{A hívóközpontok múködése}

\section{A hivóközpontokban folyó munka szervezése}

A hívóközpontokra az irodai munka nagymértékü automatizálása és felügyelete jellemző. A hívóközpont szíve az automata hivástovábbító rendszer (automated call distribution system, ACDS), amely fogadja a bejövő hívásokat és automatikusan az első éppen elérhetó dolgozóhoz továbbítja azokat, a hívással kapcsolatos, elöre beprogramozott utasításokkal együtt (1. ábra). Az ACDS különböző adatbázisokkal áll kapcsolatban, a telefon számítógépekkel áll összeköttetésben (Computer Telephony Integration, CTI).

1. ÁBRA

A hívóközpontok müködésének vázlata

(Operation Structure of Call Centres)

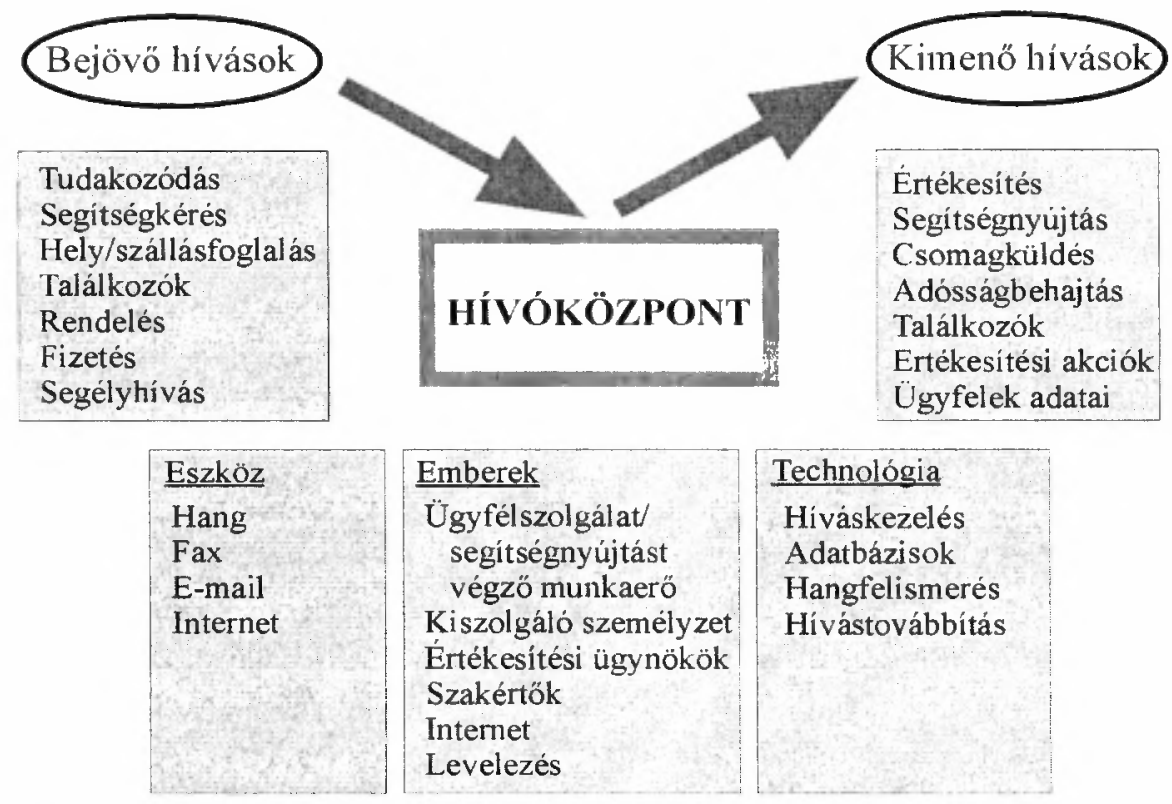

Forrás: http://business.bournemouth.ac.uk weboldal.

A telefon- és számítógépes rendszer integrálásával nem csupán a hívás jut el automatikusan a dolgozóhoz, hanem a hívó fél adatai is, az ügyfél rövid leírása, esetleg egy villogó uizenettel az operátor számára, amely bizonyos termék eladására utasítja.

Minden operátor teljesítményét elöre meghatározott mutatókkal mérik, mint amilyenek a fogadott vagy kezdeményezett hívások száma, az egy hívásra jutó időtartam nagysága és a két hívás között átlagosan eltelt időtartam. A felügyelök és a hívóközpont vezetője az ACDS rendszeren keresztül egy monitor segítségével átlát- 
Távszolgáltatások és a régiók esélyei az új területi munkamegosztásban - a hívóközpontok. Tér és Társadalom, 15. 2001. 3-4. 207-230. p.

TÉT XV. évf. 2001 @ 3-4

Kitekintö

215

ja az egész központban folyó munkát és minden egyes operátor teljesítményét bármikor ellenőrizni tudja: a monitoron megjelenik minden dolgozó neve és az éppen folytatott beszélgetés időtartama, továbbá a rendszerbe bekapcsolódott operátorok száma, a kapcsolásra váró beérkező hívások száma és a legrégebb óta várakozó hívás adatai. A felügyelö így nyomon tudja követni bármelyik operátor munkáját és ellenörizni tudja, hogy a hívások az elöre meghatározott időtartamon belül maradnak-e. Amennyiben túllépik az elöírt időtartamot, a beszélgetést folytató operátor neve villogni kezd a képernyőn, és a felügyelỏ bele tud hallgatni a beszélgetésbe, hogy kiderítse, miért olyan hosszadalmas a hívás. Természetesen bármelyik másik hívásba való belehallgatásra lehetősége van a felügyelőnek, és ezt gyakran meg is teszi.

Az ACDS rendszer akár kétszázféle statisztikát is képes készíteni. A statisztikák segítségével meg lehet határozni, hogy legalább hány operátornak kell dolgoznia a legzsúfoltabb időszakban, és legfeljebb mennyi elég a kevésbé forgalmas órákban. Így a hívóközpontokban eltőltött idő valóban effektív munkavégzéssel telik. Természetesen a teljes ellenörzés, egyes szerzők félelme ellenére (Fernie-Metcalf 1998) nem lehetséges, az alkalmazottak különböző módszerekkel ki tudják játszani a felügyelök éberségét.

\section{A munka jellege}

Az operátorok leginkább a munka intenzitását, unalmas és ismétlődő jellegét és az egész napos ügyfélszolgálattal járó stresszt szokták kifogásolni. A munka jellege nem igazán ösztönzi jobb teljesítményre az alkalmazottakat, akik közül sokan a futószalag melletti munkához hasonlítják saját tevékenységüket.

Ennek fényében nem meglepő a magas fluktuáció, az évi 20-30\%-os érték sem kimagasló. A Tyneside-i Képzési és Vállalkozási Tanács egy felmérése szerint a régióban müködő hívóközpontok alkalmazottainak éves fluktuációja 8 és 35\% között mozog, az átlag 20\% (Richardson-Belt-Marshall 2000). Mindez azonban nemcsak a munka jellegéből adódó frusztráció eredménye, hanem abból is fakad, hogy a hívóközpontok dolgozói gyakran mennek át egyik központból a másikba dolgozni, sokan pedig eleve rỏvid távra szerződnek el a hívóközpontokba, például a diákok.

Van, aki jobban bírja az állandó ellenőrzés feszültségét, van, aki kevésbé, sőt van, aki egyáltalán nem bánja, ha belehallgatnak telefonbeszélgetéseibe, mert azzal a felügyelök tudomást szereznek jól végzett munkájáról. A hívóközpontok vezetői gyakran igyekeznek a „csapatmunka” módszerével ellensúlyozni a munka árnyoldalait. A csapatszellem építése gyakran a felügyelö vagy a csoportvezető legfontosabb feladata, és számos hívóközpontot az ott dolgozók „kellemes” és „baráti” munkahelynek tekintenek.

További, a munka minőségét javító tényezők a hívóközpontok dolgozói számára biztosított környezeti és ergonómiai feltételek, amelyek általában sokkal jobbak, mint a legtöbb hagyományos irodában. 


\section{Képzettség és karrierlehetöségek}

Annak ellenére, hogy a hívóközpontok fejlett technológiát alkalmazó munkahelyek, a legtöbb esetben nem igénylik dolgozóik részéröl az alapos technológiai ismereteket vagy a magas szintủ végzettséget (kivéve a mủszaki segítségnyújtási szolgáltatást végző központokat). A hívóközpontok tulajdonosai számos olyan követelményt támasztanak azonban a dolgozókkal szemben, amelyek a „puha képességek" kategóriába tartoznak, mint a nehezen számszerüsíthető vagy mérhetö „kommunikációs képességek”, az „ügyfélszolgálati ismeretek”, vagy a „csapatmunkára való alkalmasság", de ugyanilyen fontosnak tekintik a hívóközpontok vezetői az olyan személyes tulajdonságokat, mint a türelem, tolerancia, empátia, motiváltság, elhivatottság és a stressz elviselésének képessége. Az esetek túlnyomó többségében a munkaadók sokkal fontosabbnak tartják ezeket a nehezen megfogható és számszerüsíthető ismereteket, mint a müszaki jártasságot, illetve a különböző végzettséget igazoló papírokat.

A fent felsorolt puha képességekre a hívóközpontokban folyó munka természete miatt van szükség. Az alkalmazottaktól nem csupán az ügyfél kiszolgálását várják, hanem azt is, hogy a munkaszervezet filozófiáját is közvetítse a telefonvonalon keresztül. A hívóközpontokban folyó munka azokhoz az interaktív szolgáltató tevékenységekhez hasonlítható, ahol a dolgozók személyisége, megjelenése, sőt érzelmei rendkívül fontosak a szolgáltatás folyamatában, az értékesített „termék” szerves részét képezik (Richardson-Belt-Marshall 2000). A hívóközpontokban dolgozóknak azonban ezt az „első vonalbeli” munkát gyakran rendkívül kemény nyomás alatt, munkakörülmények között kell végezniük. A hívóközpontokba ezért elsősorban olyan munkaerőt keresnek, aki az ügyfélszolgálathoz szükséges képességek mellett megfelelö motivációval és kitartással is rendelkezik.

Ezen követelmények ismeretében érthető, hogy a munkaerö folyamatos képzése miért olyan fontos elem a hívóközpontok kultúrájában. A kezdő oktatás időtartama nagymértékben eltérhet az egyes munkahelyek között, egy naptól akár hat hétig is terjedhet. A hagyományos, nagy számú irodai alkalmazottat foglalkoztató ipari vállalatokhoz képest a hívóközpontokban folyó oktatás általában strukturáltabb és szisztematikusabb, és többnyire erősen termék-orientált. A legtöbb helyen a kezdeti oktatás után folyamatosan szerveznek képzéseket, amelyeken a termékkel kapcsolatos, illetve a vevők kiszolgálásához szükséges ismeretek sajátíthatók el.

A hívóközpontokban folytatott munka számos, a vevőkkel való bánásmóddal és a kitüzött célok elérésével kapcsolatos képességet követel meg (amelyek mindegyike egyre fontosabbá válik a szolgáltató szektorban), és ezek a képességek potenciálisan konvertálhatók a többi szolgáltató tevékenységbe is, a hívóközpontok így számos új ismerettel és képességgel gazdagíthatják a régiók munkaerejét. Ezek az ismeretek azonban sem különösebb társadalmi elismertségnek nem örvendenek, sem kiemelten magas anyagi javadalmazással nem járnak. Részben ez lehet az oka annak, hogy a hívóközpontokban foglalkoztatott munkaerő jelentős része nő.

Egy, a skóciai hívóközpontokról 1997-ben végzett felmérés szerint (Bain-Taylor 1999) a központokban alkalmazott munkaerő többnyire nö, fiatal, és egyre inkább 
Távszolgáltatások és a régiók esélyei az új területi munkamegosztásban - a hívóközpontok. Tér és Társadalom, 15. 2001. 3-4. 207-230. p.

részmunkaidőben dolgozik közepes vagy nagy méretủ munkahelyen. A nő/férfi arány e felmérés szerint a következőképpen alakult: a munkaerö $67,4 \%$-a volt nő és 32,6\%-a férfi, ami megfelel a szolgáltató ágazatokat hagyományosan nöi munkának tekintő sztereotípiának. A vizsgálat évében mindössze egy hívóközpontban dolgozott több férfi, mint nö, egy olyan helyen, ahol bizonyos fokú müszaki ismeretekre is szüksség volt, de két év múlva már e helyen is a nöi munkaerő volt többségben.

A skót hívóközpontokban dolgozók tơbb mint kétharmada 35 évnél fiatalabb volt, csaknem egyharmaduk pedig még a 25. életévét sem töltötte be. A munkaerő mindössze egynyolcada került a hívóközpontokba munkaerö-közvetító ügynökségek révén, döntő többségüket $(86,4 \%)$ közvetlenül a központok vették fel.

1997-ben az alkalmazottak kétharmada fóállású, egyharmada pedig mellékállású volt. A munkaadók azonban egyre inkább a részmunkaidöben foglalkoztatottak arányát növelik, így elöbb-utóbb a részmunkaidős alkalmazottak túlsúlyba kerülhetnek. Érdekes, hogy míg a férfiaknak csupán pontosan egynegyede, addig a nōi alkalmazottak több mint egyharmada volt részmunkaidős.

A hívóközpontokban a karrier lehetöségét nagyban befolyásolja a központok rendkívül „lapos” szervezeti felépitése. A skót felmérés adatai szerint az összes alkalmazott csaknem kétharmada operátor/tanácsadó volt, az egyéb adminisztrációs alkalmazottak további $11,6 \%$-ot tettek ki, a munkaerö mintegy nyolcada volt felügyelő és menedzser, a fennmaradó $4 \%$-ot pedig a müszaki alkalmazottak alkották. A vizsgált hívóközpontokban dolgozóknak mindössze 8,4\%-a rendelkezett egyetemi diplomával, $1,4 \%$-a további posztgraduális végzettséggel, nagyobb részük legfeljebb érettségivel.

A legtöbb hívóközpontban a munka intenzív és szabványosított jellege nem teszi lehetövé, hogy az operátorok továbbfejlesszék ismereteiket vagy képességeiket. A dolgozók a monitoron megjelenő utasításokat követik, kevés döntési szabadságuk van. Az autonóm döntési szabadság hiánya, illetve az egész napos, ügyfelekkel való törỏdés és a kitüzött céloknak való megfelelés kényszere miatt sokan „kiégnek” és a legtöbb hívóközpontban nagymértékủ a fluktuáció (ez a jelenség azonban nem csak a hívóközpontokra jellemzö, az irodai munka intenzívebbé válásával sok más munkahely is hasonló problémákkal küzd).

Azok számára, akik a hívóközpont-ágazatban szeretnének karriert építeni, a lehetőségek az adott régión belül általában korlátozottak a hívóközpontok többnyire csak három vagy négy szintet magában foglaló hierarchikus szerkezete miatt (operátor, csapatvezető, felügyelő és menedzser). A felügyelöi és menedzseri álláshelyek száma alacsony, ezért néhány hívóközpontban további szinteket vagy operátorpozíciókat alakítottak ki, hogy ezzel motiválják a munkaeröt, ezek a kezdeményezések azonban nem terjedtek el széles körben. Ha valaki tehát az adott cégen belül szeretne karriert csinálni, azt többnyire csak ugyanannak a vállalatnak más régióbeli telephelyein teheti meg. 


\section{A fluktuáció problémája}

A hívóközpontok egyik legnagyobb problémája a munkaerő többnyire igen magas fluktuációja. Az új alkalmazottak felvétele és képzése, a munkára való felkészítése hatással van a vállalkozások müködésének hatékonyságára: a dolgozókkal meg kell ismertetni a cég termékeit vagy szolgáltatásait, ki kell öket képezni az alkalmazott technológia használatára, illetve az ügyféllel folytatott beszélgetésekkel kapcsolatos tudnivalókra, és a képzés ideje alatt profitot aligha termelnek a cég számára. A képzés hossza és költségei szervezetenként eltéröek, de a hívóközpontokat tömörítő Call Centre Association azokat alkalmazottanként átlagosan 2000 angol fontra becsüli (1999-es adat). Minél nagyobb tehát egy cégnél a fluktuáció, annál többet kell a vállalkozásnak oktatásra és új alkalmazottak felvételére költenie.

A fluktuáció mértékéről hivatalos adatok ritkán állnak rendelkezésre, a cégek többnyire éves szinten 20-30\%-os arányt vallanak be (ami a valóságban akár a duplája is lehet). A cégek nem szívesen adják ki a dolgozóik fluktuációjával kapcsolatos adatokat, emellett azt a munkaerö összetett jellege (például a részmunkaidőben foglalkoztatottak aránya) is torzítja. Általában túlságosan alacsony számokat tesznek kỏzzé, kozmetikázzák adataikat, illetve az alacsonyabb fluktuációval jellemezhető cégek szívesebben nyilatkoznak erröl az adatról, mint azok, ahol a munkaerő nagyobb része cserélődik ki minden évben. (Az 1997-es skóciai felmérés során volt olyan cég, ahol az éves fluktuáció egyszámjegyủ értéket mutatott, de volt olyan is, ahol ez a szám meghaladta a $80 \%$-ot, sőt olyan cég is akadt, ahol hónapok óta először csökkent évi 100\% alá ez az érték.) A Mitial Group felmérése szerint (idézi Bain-Taylor 1999) az Egyesült Királyság egészére számított éves fluktuáció mértéke $16 \%$ volt, ami azonban jelentős regionális különbségeket takart - Crewe-ban és Skóciában mindössze 5\% volt, Sheffield, Belfast, Coventry városokban, ÉszakKentben és Cumbriában szintén 10\% alatt maradt, míg három dél-angliai helyszínen $40 \%$ közelében mozgott (Watford 42\%, Basingstoke 40\%, Swindon 39\%), London és Leeds hívóközpontjaiban pedig évente a munkaerő 34\%-a cserélödött ki. Összefüggés mutatható ki a fluktuáció aránya és a bérek nagysága között: ahol magas a fluktuáció, ott a cégeknek több pénzbe kerül a munkaerő megtartása, illetve az újonnan munkába állók kiképzése. Tizenhárom olyan hívóközpont közül, ahol a fizetésemelés mértéke meghaladta az évi 5\%-ot, hét az ország déli részén (ahol a fluktuáció mértéke a legnagyobb) található (Bain-Taylor 1999).

A fluktuációnak számos oka van. A munka, természetéből fakadóan, embert próbáló, taylorista elvek szerint szervezödik. Az automata híváselosztó rendszer a bejövő hívásokat az első éppen rendelkezésre álló operátor felé továbbítja, a kimenő hívásokat pedig szintén az automata irányítja a dolgozók felé, akiknek így szinte semmi lehetöségük nincs arra, hogy befolyásolják a munka ütemét. A hívások közt eltelt időt figyelik és nyilvántartják, a hívások előre leírt „recept” szerint történnek, kreativitásnak és változatosságnak általában nyoma sincs - a munka így természetesen meglehetősen megeröltetỏ és unalmas.

Az olyan mérhető, ,kemény” mutatók, mint a hívások hossza, a hívások közt eltelt időtartam stb. mellett a munkaadók olyan ,puha", nehezen megfogható ténye- 
Távszolgáltatások és a régiók esélyei az új területi munkamegosztásban - a hívóközpontok. Tér és Társadalom, 15. 2001. 3-4. 207-230. p.

zőket is megkövetelnek az alkalmazottaktól, mint az ügyfél iránt tanúsított udvariasság, elhivatottság, a telefonbeszélgetés tartalma, "mosolyogni a telefonba" azaz a munka nem csupán fizikailag, hanem érzelmileg is meglehetősen kimerítő.

A hívóközpontok müködésében nyoma sincs a megszokott „,reggel nyolctól délután fél ötig" munkaidőnek, sőt, sok esetben évi 365 napon és napi 24 órában múködnek a központok (elsősorban a bankszektor és bizonyos segítségnyújtási tevékenységeknél), vagy meghosszabbított nyitva tartással (beleértve a hétvégéket is) üzemelnek, például a biztosítási, utazási és közmü-szektorban. A folyamatos teljesítmény-kényszer és a hosszú (és gyakran kellemetlen beosztású) munkaidő nem túl vonzó körülmény, amin sok esetben rövid, napi négy órás müszakra felvett alkalmazottak munkába állításával próbálnak segíteni (ez a megoldás a munkaadók szerint a stresszt is sokkal türhetőbbé és kezelhetőbbé teszi).

A fent felsorolt tényezők együttesen vezetnek a munkaerő „kiégéséhez” és a magas fluktuációhoz. Ugyanakkor a központok teljesítményét nem befolyásolhatja a munkájukba belefáradó, fásult operátorok csökkenö hatékonysága és romló teljesítménye, ezt pedig csak új munkaerő folyamatos beállításával lehet megoldani.

\section{A hivóközpontok foglalkoztatottságának fenntarthatósága}

A hívóközpontnak a regionális gazdaságban, foglalkoztatáspolitikában játszott szerepének vizsgálatakor nem kerülhetjük meg a létrehozott munkahelyek hosszú távú perspektíváit, fenntarthatóságát. Két tényezó veszélyezteti a munkahelyek számának további növekedését, illetve a régión belül tarthatóságát: a többi régió versenye, illetve hosszabb távon még ennél is nagyobb mértékben az ágazat müszaki fejlödése.

A hívóközpontok megtartása és újak letelepítése megfelelő méretủ munkaerökínálatot és innovatív támogatási mechanizmusokat kíván (az északkelet-angliai régió például ösztönzörendszerével vonzott számos hívóközpontot). Az Egyesült Államok tapasztalatai azt mutatják, hogy bizonyos szolgáltatások követték a feldolgozóipar példáját és a fejlödő országok alacsonyabb költségủ telephelyeire telepítették át tevékenységüket (Richardson-Belt-Marshall 2000). Föleg az adatbevitel és szoftverfejlesztés területén jellemző ez, de vannak már példák a telemarketingtevékenységek kitelepítésére is.

Mindeddig arra még nem volt példa, hogy európai hívóközpont a fejlödő országokba települt volna (Richardson-Belt-Marshall 2000), az azonban gyakran elöfordul, hogy az európai országokból kezdeményezett hívásokat az időeltolódás miatt máshová irányítják, ahol éppen nappali időszak van, és fordítva az európai hívóközpontok így adnak át munkát a világ más részeinek.

Természetesen nem zárhatjuk ki annak a lehetöségét, hogy a hívóközpontok Európából más kontinensekre települjenek át, ennek azonban egyelöre számos akadálya van: a müszaki költségek, a szabályozási rendszerek eltérései, a szervezeti és üzleti környezet különbségei, nyelvi és kulturális korlátok. 
A technológiai fejlödés nagyobb veszélyt jelent a hívóközpontok alkalmazottai számára. A müszaki fejlesztések e tekintetben két csoportra oszthatók: egyfelöl azokra a technológiákra, amelyeket már ma is alkalmaznak (automata híváselosztó rendszer, számítógépesített telefonközpontok, programozott hívóautomata, interaktív válaszadó rendszer), és amelyek további fejlödése befolyásolhatja a hívóközpontban szükséges operátorok számát. Az egyre kifinomultabb technológia egyfelől kevesebb operátor munkáját igényli, ugyanakkor a hívóközpontok költséghatékonyabbá tételével más elosztási csatornák rovására növelheti is a hívóközpontokban a munkahelyek számát.

A programozott hívóautomata egy elöre beprogramozott telefonkönyvet, az ügyfelek adatait tartalmazza, és meghatározott sorrendben „felhívja” öket. Amennyiben a hívott fél felveszi a telefont, a rendszer a hívást automatikusan átadja egy elérhetö operátornak, akinek a képernyőjén egyidejüleg megjelennek az ügyfél legfontosabb adatai és a számára átadandó üzenet, szöveg. Ezt a technológiát a marketing, az értékesítés és az adósságbehajtás területén alkalmazzák, az operátornak kevesebb időt kell az ügyféllel töltenie, és megszabadul a folyamatos tárcsázás, esetleg félretárcsázás fáradalmaitól. A hagyományos tárcsázással szemben akár $200 \%$-os hatékonyságnövekedést lehet így elérni, legalábbis az ilyen rendszerek szállítói szerint.

Talán az interaktív ügyfélszolgálati rendszer jelenti a legnagyobb veszélyt a hívóközpontok foglalkoztatottságára. Az ügyfelek különböző menüpontok segítségével maguk juthatnak hozzá a kért információhoz, vagy adhatnak fel megrendeléseket. $\mathrm{Az}$ interaktív ügyfélszolgálati rendszer terjedőben van, és ugyan nem szorítja ki teljesen a hagyományos operátorokat (akik alternativ lehetőségként megmaradnak az ügyfél számára), de például az információszolgáltatás és a termékrendelés területến bizonyosasan kevesebb alkalmazottra van szükség e renđszerek munkába állítása után. A vevőgondozás funkciója azonban továbbra is a humán szektor szerepe marad, jelentős változásnak kell történnie a vásárlói szokásokban és ügyfélkultúrában, mielött az emberek elfogadják a teljes mértékben automatizált, interaktív rendszereket. Az emberi oldal, az operátorok olyan hozzáadott értéket jelentenek a hívóközpontok müködésében, amire a gépek nem képesek.

A technológia másik csoportja az elektronikus kereskedelem körébe tartozik, mint az Internet, intranetek, illetve a digitális televíziókészülékek. Ezek az interaktív eszközök csökkenthetik több hívóközpontban a foglalkoztatottak számát, ehhez azonban két dolog szükséges: egyrészt, hogy azok a cégek, amelyek most hívóközpontokkal szolgálják ki ügyfeleiket, beruházzanak az új technológiákba, másfelöl, hogy az ugyfelek is megtegyék ugyanezt. A cégek beruházásai megindulni látszanak, az ügyfél-oldalon több a bizonytalanság. Hosszabb távon valószínünek tünik, hogy ezek a technológiák jelentős szerepre tesznek szert az elektronikus kereskedelemben. Az Egyesült Királyságban a cégek kezđik átalakítani telefon-alapú szolgáltatásaikat az Internet használatára, elsösorban a bankszektor és a biztosítás terưletén.

Az új technológiák és a telefonra alapozott ügyfélszolgálati tevékenység valószínủleg még hosszabb ideig egymás mellett fognak élni. Vannak olyan cégek, amelyek az Internettel és a telefonos ügyfélszolgálattal elérhetó ügyfeleket külön piac- 
nak tekintik. Egyes szervezetek már felvették az Internetet is szolgáltatási csomagjukba, gyakran hívóközponttal összekötve, ahol az ügyfél egy weboldalról klikkelhet a hívóközpont számára és kerülhet kapcsolatba az operátorral. Az Internet ilyen használata a hívóközpontok jelentőségét emelheti ki és mindkét ügyfélszolgálati megoldás létjogosultságát bizonyítja, hosszabb távon azonban valószínüleg hozzájárul azoknak a hívóközpontoknak a megszủnéséhez, amelyek alacsonyabb színvonalú feladatokat végeznek.

\section{Néhány frekventált európai hívóközpont-telephely rövid bemutatása}

A Datamonitor becslései szerint (a Call Centre Assocation adatszolgáltatása szerint) az Egyesült Királyságon kívül az 1. táblázatban szereplö európai országokban müködik jelentős számú hívóközpont.

A legnagyobb európai hívóközpont-csoportosulás azonban a Brit-szigeteken található. A Datamonitor becslései szerint 5050 hívóközpont müködött az Egyesült Királyságban 2000-ben, 2001-re 5210, míg 2002-re 5370 központtal számolnak. A Távközlési Dolgozók Szakszervezete tágabb határok között, 1500-5000 közé teszi számukat, a Mitial Research szerint 3450 a definíciójának mindenben eleget tevö brit hívóközpontok száma, amely 2001 végére 3950-re emelkedhet.

\section{TÁBLÁZAT}

Hivóközpontok Európában, 2000-2001

(Call Centres in Europe)

\begin{tabular}{lcc}
\hline \multicolumn{1}{c}{ Ország } & $\begin{array}{c}\text { Hívóközpontok száma } \\
\text { 2000-ben }\end{array}$ & $\begin{array}{c}\text { Hívóközpontok száma } \\
\text { 2001-ben }\end{array}$ \\
\hline Németország & 2450 & 2875 \\
Franciaország & 2420 & 2610 \\
Olaszország & 1020 & 1190 \\
Spanyolország & 1010 & 1150 \\
Hollandia & 990 & 1045 \\
Svédország & 630 & 665 \\
Dánia & 380 & 400 \\
Norvégia & 320 & 340 \\
\hline
\end{tabular}

Forrás: Call Centre Association adatközlése, 2001. október.

A brit hívóközpontok tevékenység szerinti megoszlása a következö: pénzügyi szolgáltatások $32 \%$; távközlés $14 \%$; marketing-kommunikáció és -kutatás $5 \%$; közmüvek 5,5\%; vendéglátás/szórakoztató ipar 4,5\%; kiskereskedelem 7\%; informatika 4,5\%; közlekedés 3,5\%, egyéb $24 \%$ (Call Centre Association adatszolgáltatása). 
A Mitial egy 2000-ben készült jelentése szerint az Egyesült Királyságon belül a 10 legfontosabb hívóközpont-telephely a következö:

1. Belfast

2. Dearne-völgy

3. Északkelet-Anglia

4. Dél-Yorkshire

5. Dublin

6. Shannon

7. Liverpool

8. Bangor, Észak-Wales

9. Észak-Ayrshire

10. Highlands \& Islands

A fent felsorolt régiók közül Északkelet-Angliát, Írországot és Skóciát mutatjuk be röviden az alábbi fejezetben.

\section{Északkelet-Anglia}

A hívóközpontban foglalkoztatottak számát tekintve Északkelet-Anglia közepes pozíciót foglal el (2. ábra). 1998-ban országos szinten az összesen 121000 operátori munkahellyel rendelkező szektornak csak mintegy 6\%-a (7260 munkahely) volt a régióban, ami ugyanakkor e térség gazdasági szerkezetén belül a hívóközpontok országos átlagnál nagyobb arányára utal, az Egyesült Királyság teljes munkaeröállományából az északkeleti régió részesedése ugyanis még az 5\%-ot sem éri el.

\section{2. ÁBRA}

A hívóközpontokban alkalmazottak eloszlása az Egyesült Királyság régiói közt, 1998

(Persons Employed in Call Centres by Regions in the United Kingdom)

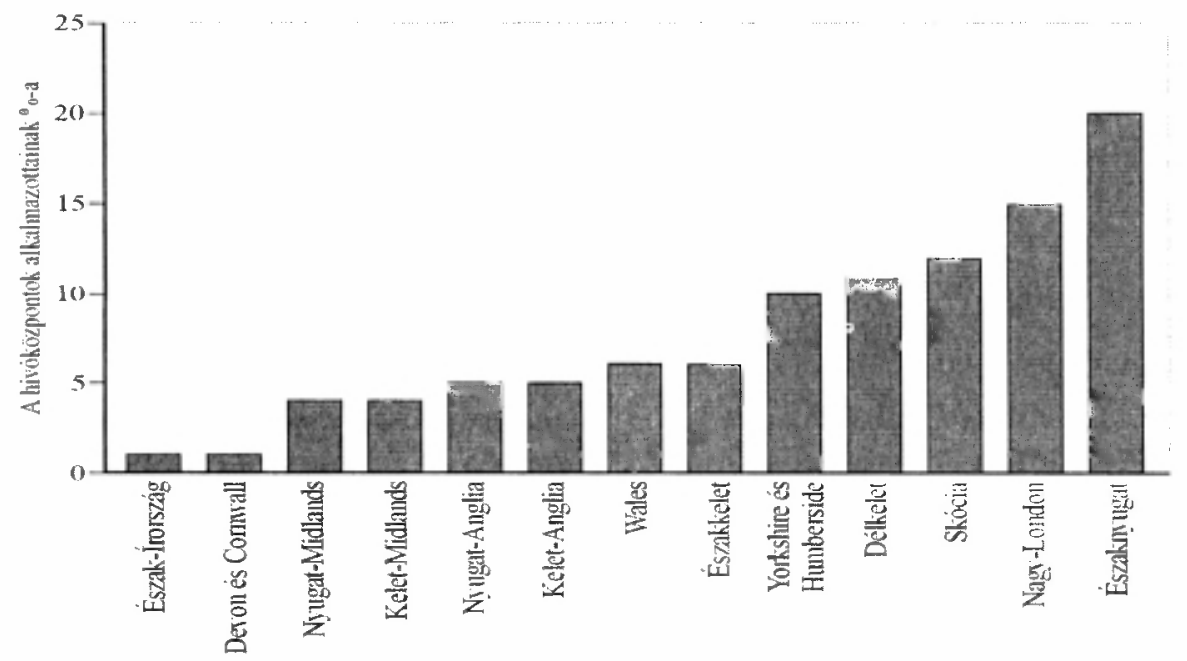

Forrás: Richardson-Belt-Marshall 2000, 361. 
Távszolgáltatások és a régiók esélyei az új területi munkamegosztásban - a hívóközpontok. Tér és Társadalom, 15. 2001. 3-4. 207-230. p.

TÉT XV. évf. 2001 - 3-4

Kitekintö

223

Az északkeleti régióban az operátorok mintegy $70 \%$-a nő, bár ez az arány a férfiak egyre nagyobb arányú munkába állásával csökken. Az Egyesült Királyságban az első hívóközpontok üzemeltetői elsősorban részmunkaidős munkaerót alkalmaztak a költségcsökkentés és a rugalmasabb munkaszervezés érdekében. Az elmúlt években e téren változás következett be, ma a hívóközpontok munkaerejének mintegy 70\%-a teljes munkaidős alkalmazott és csak mindössze egynegyedük részmunkaidős (bár egyes cégeknél, például a British Telecom-nál még mindig ők vannak többségben). Ez egyrészt a munkaeröpiac átalakulásának köszönhető, az 1990-es évek második felének élénkebb munkaeröpiacán kevesebben voltak hajlandók részmunkaidős állást vállalni, másrészt a szektorra jellemző magas fluktuáció miatt a munkaadók általában hosszabb munkaidőt ajánlanak fel, hogy megtartsák az alkalmazottakat, harmadrészt a magas betanítási költségek és egyéb, humán erőforrásokkal kapcsolatos kiadások miatt költséghatékonyabb a hívóközpontokban fóállásban alkalmazni a dolgozókat.

Északkelet-Angliában a pénzügyi szolgáltatások és a távközlési ágazat alkalmazza a legtöbb embert a hívóközpontokban (2. táblázat), a 38 legjelentösebb hívóközpontból $11(29 \%)$ a pénzügyi szolgáltatások, míg $10(26 \%)$ a távközlés területén müködik. A harmadik legnagyobb szektor a „megbízásos” hívóközpontoké, amelyek más cégek nevében szerződnek munkák elvégzésére. Az energiaszolgáltatás, utazás, közlekedés és idegenforgalom, illetve a kormányzati szolgáltatások is jelen vannak a régióban.

A foglalkoztatottak számát illetỏen a távközlési szektor az első, az összes munkaerő mintegy $37 \%$-a dolgozik e szektorban, a második helyen a pénzügyi szolgáltatások állnak 27\%-kal (három pénzügyi szolgáltató cég azonban nem közölte alkalmazottainak számát, így e szektor pontos részaránya nem ismert). A pénzügyi szolgáltató vállalkozások tervezett növekedése következtében hamarosan e szektor lehet a legnagyobb foglalkoztató a hívóközpontokban.

A régiónak, bár számos hívóközpont müködik itt, van néhány gyengesége is:

- A régió hívóközpontjai többnyire régión kívüli vállalatokhoz tartoznak, ami a térséget függő helyzetbe hozza. A legtőbb telepítő tényező tekintetében a régió nem rendelkezik egyértelmủ versenyelőnnyel. A viszonylag fejlett távközlési rendszer alapfeltétel a hívóközpontok müködésében, e tekintetben pedig Északkelet-Anglia nem áll jobban, mint az Egyesült Királyság többi régiója (az igényeknek elébe menő infrastruktúra-beruházások a Newcastle Business Park és a Doxford Park területén történtek, amelyekbe jelentös számú hívóközpont telepedett le). A rendelkezésre álló földterület, a célnak megfelelő és olcsó épületek jelentettek még fontos telepítő tényezöt, míg a vállalkozási övezet és képzési hozzájárulások, bár számos cég vette igénybe e szolgáltatásokat, a legtöbb vállalkozás szerint csak hab volt a tortán, de semmiképpen nem a fó vonzeró, amiért ide települtek. A legfontosabb telepítő tényező a többi régiónál olcsóbban beszerezhetỏ, megfelelően képzett és elegendỏ számban rendelkezésre álló munkaerö. 


\section{TÁBLÁZAT}

Az északkelet-angliai export-orientált hivóközpontok néhány jellemzóje, 1998 (Some Characteristics of Export-oriented Call Centres in Northeast England)

\begin{tabular}{|c|c|c|}
\hline Vállalat neve & Telephely & Ágazat \\
\hline National Savings & Durham & Kormányzati szolgáltatások \\
\hline Eagle Star Direct & Newcastle városközpont & Pénzügyi szolgáltatások \\
\hline Rail Direct & Newcastle városközpont & Utazás \\
\hline Newcastle Direct & Newcastle városközpont & Pénzügyi szolgáltatások \\
\hline GNER & Newcastle városközpont & Utazás \\
\hline Going Places & Newcastle és Sunderland & Utazás \\
\hline Matrixx Marketing & Newcastle városközpont & Szerzödéses hívóközpont \\
\hline EAGA & Newcastle városközpont & Energiaszolgáltatás \\
\hline AA Insurance & Newcastle Business Park & Pénzügyi szolgáltatások \\
\hline Thistle Comms & Newcastle Business Park & Távközlés \\
\hline British Airways & Newcastle Business Park & Utazás \\
\hline Northern Rock & Newcastle, Regent Centre & Pénzügyi szolgáltatások \\
\hline Sage & Newcastle, Benton Park Road & Szoftver-szolgáltatások \\
\hline BT (bejövő hívások) & $\begin{array}{l}\text { Newcastle, Gateshead, } \\
\text { Sunderland, Darlington, } \\
\text { Middlesborough }\end{array}$ & Távközlés \\
\hline Avco & Sunderland, Doxford Park & Pénzügyi szolgáltatások \\
\hline Axciom & Sunderland, Doxford Park & Szerződéses hívóközpont \\
\hline SSL & Sunderland, Doxford Park & Szerződéses hívóközpont \\
\hline London Electric & Sunderland, Doxford Park & Energiaszolgáltatás \\
\hline One-to-One & Sunderland, Doxford Park & Távkỏzlés \\
\hline Royal \& Sun Alliance & Sunderland, Doxford Park & Pénzuigyi szolgáltatások \\
\hline Littlewoods & Sunderland & Kiskereskedelem \\
\hline BT (kimenő hívások) & $\begin{array}{l}\text { North Tyneside, Gosforth } \\
\text { Business Park }\end{array}$ & Távközlés \\
\hline Abbey National & Stockton, Teesdale Business Park & Pénzuigyi szolgáltatások \\
\hline Barclaycard & Stockton, Teesdale Business Park & Pénzügyi szolgáltatások \\
\hline Starpak & Hartlepool & Számítógépes segítségnyújtás \\
\hline RAC Insurance & Darlington & Pénzủgyi szolgáltatások \\
\hline Hutchinson Telecom & Darlington & Távközlés \\
\hline Amott Insurance & Fencehouses & Pénzügyi szolgáltatások \\
\hline Natwest & Gateshead, Team Valley & Pénzügyi szolgáltatások \\
\hline Topline & Gateshead, Vance Business Park & Szerzödéses hívóközpont \\
\hline Mailcom & Gateshead, Follingsby Park & Szerzödéses hívóközpont \\
\hline Child Benefits Agency & Washington & Kormányzati szolgáltatások \\
\hline Vodafone & Washington & Távközlés \\
\hline Transco & Killingworth Town Centre & Energiaszolgáltatás \\
\hline
\end{tabular}

Forrás: Richardson-Belt-Marshall 2000, 361.

- Kevés a „fejlett szolgáltatást nyújtó” hívóközpont. Csak két cég müködik az általában képzettebb munkaerőt igénylö és jobban fizető számítógépes szolgáltatások szektorban, és mindössze három cégnél magas azoknak az alkalmazottaknak az aránya, akik idegen nyelvet beszélnek.

- Csak kevés helyi cég használja fel a hívóközpontokat arra, hogy földrajzi értelemben kiterjesszék piacaikat. 
Távszolgáltatások és a régiók esélyei az új területi munkamegosztásban - a hívóközpontok. Tér és Társadalom, 15. 2001. 3-4. 207-230. p.

TÉT XV. évf. 2001 - 3-4

Kitekintó

225

- A hívóközpontok földrajzilag egy szük területen, elsősorban a városközpontokban koncentrálódnak. Az összes hívóközpont 42\%-a három helyen található (Newcastle városközpontja, a Newcastle Business Park és a Doxford Park), így kevés település élvezi a hívóközpontok jelenlétének az előnyeit. A hívóközpontok lassan mozognak lefelé a városhierarchián.

- Míg országosan gyorsan fejlödnek a hívóközpontokat segítő háttérszolgáltatások (képzés, szoftverfejlesztés, speciális üzleti szolgáltatások), az északkelet-angliai régióban ennek nem sok jele mutatkozik. Természetesen a hívóközpontok máshonnan is könnyedén be tudják szerezni a müködésükhöz szükséges szolgáltatásokat, a régiót azonban így nem érinti a hívóközpontok növekedésével előálló foglalkoztatásî multiplikátor-hatás (Bain-Taylor 1999).

\section{Írország}

Írország az elmúlt évtizedekben intenzíven fejlesztette oktatási rendszerét, aminek következtében a magasan képzett és viszonylag olcsó munkaerövel jelentös vonzeröt jelentett (és jelent ma is) a külföldi befektetések számára. Az 1980-as években nagyszabású beruházásokat eszközölt az ország a fejlett távközlési technológiákba, és ma is nagyon kedvező nemzetközi telefondíjakat kínál. Nyelvileg és kulturális téren sok hasonlóságot mutat az Egyesült Államokkal, igen stabil a politikai rendszere és a társadalmi környezete, az ír kormány rendkívül pozitívan viszonyul a külföldi beruházásokhoz, alacsony a társasági nyereségadó, számos tőkejuttatás, képzési hozzájárulás, tanácsadási és egyéb szolgáltatás áll a betelepülỏ vállalkozások rendelkezésére, a profitot viszonylag könnyen ki lehet vinni az országból, a nemzeti valuta viszonylag stabil és nem korlátozzák törvények a tỏkemozgást. Az Egyesuilt Államok szempontjából különösen kedvező emellett a legalább 5 órás időeltolódás. Mindezek miatt Írország a hívóközpont-iparág egyik legjelentősebb európai központjává vált.

A hívóközpontok fejlödését Írországban elsősorban a cégek részéröl az ügyfélszolgálati tevékenységekre fordított megnövekedett figyelem és a direkt marketing terjedése, illetve az egyre több helyen rendelkezésre álló olcsó és magas színvonalú távközlési infrastruktúra mozdította elö. A nagyobb cégek igyekeznek müködésüket centralizálni a méretgazdaságosság jegyében. Számos nagy hívóközpontot zöldmezős beruházásként építettek fel, ahol könnyebb volt elfogadtatni az új munkakultúrát, a szokatlan munkaidő-beosztást és könnyebb volt a béralku, mint a már múködő telephelyeken.

Általában a legtöbb hívóközpont a nemzeti piac kiszolgálására törekszik, Írországban azonban a nemzetközi tevékenységet folytató hívóközpontok is rendkívül jelentősek. Az Európai Unióban a hívóközpontok centralizációja az Európa számos országában müködő nagy cégek termelésének, marketing-tevékenységének és ügyvitelének racionalizálása jegyében zajlik. Írország gyorsan felfigyelt erre a lehetöségre és magát alkalmas összeurópai hívóközpont-telephelyként reklámozta, a meglévő támogatások és adókedvezmények mellett a legalacsonyabb európai nemzet- 
közi telefontarifákat és olcsó, jól képzett, rugalmas és nyelveket beszélö munkaerỏt kínálva. Az ír Iparfejlesztési Hatóság, az IDA 1992-ben hirdette meg hívóközpontprogramját, a 2000. évre 3000 munkahely megteremtését célul kitüzve. Ezt a számot már 1996 elejére elérték, 1998-ra pedig Írország mintegy 50 hívóközpontjában 6000 ember dolgozott.

$\mathrm{Az}$ îr hivókőzpont-szektorban az amerikai cégek vannak legtöbben, a vállalkozások 70\%-át teszik ki és a munkaerö 80\%-át foglalkozatják. Az IBM, Compaq, Dell, Citibank, Hertz és az Oracle a legjelentösebb amerikai vállalatok. Az összes alkalmazott mintegy 70\%-a itt is nö, arányuk magasabb az alacsonyabb végzettséget igénylő szálláshely-foglalási és értékesítési alágazatban és alacsonyabb a segítségnyújtási tevékenységek terén, ahol Bizonyos müszaki végzettségre van szükség (és amelyik általában jobban fizetett munka).

A nők magas arányát jobb kommunikációs képességük és általában jobb idegennyelv-tudásuk magyarázza, ami Írországban a nemzetközi tevékenységet folytató hívókőzpontok nagy száma miatt kủlönösen fontos tulajdonság. A hívóközpontok háromnegyede számára a nyelvtudás az egyik legfontosabb telepítỏ tényezó Írországban. Az alkalmazottak több mint fele (55\%-a) használ idegen nyelvet munkája során, akik 43\%-a külföldi állampolgár, azaz az összes alkalmazott 23\%-a külföldi. Az ír nemzetiségủ alkalmazottak általában a nagyobb európai nyelveket (francia, német, olasz, spanyol), a külföldiek a kevésbé széles körben beszélt európai (skandináv nyelvek, holland, portugál), illetve a nem európai (például koreai, japán) nyelveket használják.

Az összes alkalmazott $90 \%$-a a dublini régió hívóközpontjaiban dolgozik. Hiába áll rendelkezésre fejlett távkőzlési infrastruktúra Írország egészében, a hívóközpontok nem szívesen mozdulnak ki a főváros területéről, attól félve, hogy nem találnak elegendỏen nagy számú nyelvet, elsősorban a ritkább nyelveket beszélő munkaerỏt, aggódnak emellett az irodák és a háttérszolgáltatások Dublinon kívüli elérhetősége miatt is. Még Dublinban is egyre nehezebb megfelelő munkaerőt találni, akiknek a nyelvismerete és egyéb képességei (professzionális telefon- és számítógéphasználat, illetve müszaki ismeretek) is megvannak. Részben a szektor gyors növekedése miatt igen magas a fluktuáció, ami a telemarketing területén az évi $37 \%$-ot is eléri, az ügyfélszolgálat esetében $25 \%$ körül mozog, míg a műszaki segítségnyújtásnál (a szektorban a legjobban fizetett tevékenységnél) mintegy 17\%. A magas fluktuációt ugyanazok a tényezők váltják ki, amelyekről korábban már szó esett: rutinszerủ és intenzív munka és állandó ellenörzés. Ez elsősorban az alacsonyabb képzettséget igénylő központok esetében igaz. A magasabb müszaki felkészuiltséget igénylő központoknál viszont az okoz gondot, hogy a frissen végzett ír informatikusok, akik általában férfiak, többnyire nem beszélnek idegen nyelvet a kívánt szinten (tanulmányaik során a nỏk Írországban is nagyobb figyelmet fordítanak nyelvi képzésükre), így erre a munkakörre egyre több külföldit kell felvenni.

frországban található az összes nyugat-európai nemzetközi hívóközpont mintegy 30\%-a, legnagyobb részuik Dublinban. Amint azt Sassen (idézi Breathnach 2000) megjegyezte: az információs technológiák, amelyekre gyakran úgy tekintenek, mint 
Távszolgáltatások és a régiók esélyei az új területi munkamegosztásban - a hívóközpontok. Tér és Társadalom, 15. 2001. 3-4. 207-230. p.

TÉT XV. évf. 2001 - 3-4

Kitekintö

227

a földrajzi egyenlötlenségek megszüntetőjére, valójában a térbeli koncentrációt segítik elő. A hívóközpontok (is) elősegítették Îrország perifériális helyzetének megszủnését, azonban a szektor nagymértékủ nemzetközi orientációja és müszaki fejlödése miatt az ország továbbra is függő helyzetben van a nemzetközi munkamegosztásban. Az általános képzettségi szint emelkedésével az életszínvonal is javult az országban, a hívóközpontokban azonban az átlagbér alacsonyabb, mint a gazdaság legtöbb más ágazatában. Az 1990-es évek gyors növekedése nem tünik fenntarthatónak, és Írország hamarosan elvesztheti vonzerejét mint nemzetközi hívóközpont-telephely. Az IDA ezen úgy próbál segíteni, hogy további kedvezményekkel igyekszik vonzani nem dublini telephelyekre a hívóközpontokat, hosszabb távon azonban az ország valószínüleg elveszíti vonzerejét és a nem hazai tulajdonú hívóközpontok máshová települnek: hiszen ezek igen kevés helyi kỏtődéssel rendelkeznek és könnyedén mozognak egyik helyröl a másikra, ha ott kedvezőbbek a feltételek (Breathnach 2000).

\section{Skócia}

Egy 1998 második felében végzett felmérés alapján a Locate in Scotland kiadvány 159 hívóközpontról beszélt Skóciában, szemben a tizenkét hónappal azelötti mintegy 119 központtal. A becslések szerint több mint 21000 ember dolgozott a szektorban, 1997-ben számuk még csak 16000 volt. 1998 októbere és 1999 augusztusa között számos cég jelentette be, hogy új hívóközpontokat szándékozik nyitni Skóciában, ami 37 000-re növelte az alkalmazottak számát a 2000. év elejére. Ez a teljes skót munkaerö-állomány közel $2 \%$-át jelenti.

Taylor és Bain vizsgálata (1999) 52 skóciai hívóközpontra terjed ki, ezek közül csak 12 (23\%) kezdte meg müködését 1993 előtt, általában régóta műkỏdő utazási irodák és közmủvállalatok, akik az ügyfelekkel történő napi kapcsolattartásban számítottak egyre nagyobb mértékben a fejlett távkơzlési technológiákra. Az 1990-es évek gyors növekedésének ,elsö hulláma” többnyire a pénzügyi szektorra korlátozódott, különösen az akkor innovatívnak számító First Direct (banki szolgáltatások) és Direct Line (biztosítási szolgáltatások) sikeres müködésének láttán. A pénzügyi szolgáltató vállalkozások többnyire hagyományos bankfiókjaik bezárásával párhuzamosan nyitották meg hívóközpontjaikat. Elöször a nagyvállalatok voltak azok, amelyek kőltségeiket az ügyfélszolgálat „hátsó irodákba” történő összevonásával igyekeztek csőkkenteni és meglévő ügyfél-adatbázisukra építve próbálták növelni értékesítésük volumenét új, közvetlen telefonos értékesítési technikákkal. Idővel aztán jelentősen csökkentek a gazdasági tevékenységekkel és/vagy a hívóközpontok méretével kapcsolatos korlátok, és ma már a hívóközpontok a gazdaság számos ågában eredményesen müködnek.

Jelenleg a pénzügyi szolgáltatások területén müködik a legtöbb (42) skóciai hívóközpont (Locate in Scotland 1999, idézi Bain-Taylor 1999), a távközlési ágazatban múködő központok száma 38 (ebből a British Telecom egymaga 27 hívóközpontot múködtet), 12 központ a közművállalatoké, az utazási és szállítmányozási ipar 11 központtal van jelen Skóciában. Az utóbbi évek egyik leggyorsabban növekvő 
szektora az úgynevezett szerzödéses hívóközpontok, amelyek más vállalat vagy vállalatok megbízásából végeznek ügyfélszolgálati és/vagy telemarketingtevékenységet. Több skót önkormányzat tervezi, hogy közigazgatási területén tanácsadással és információ-szolgáltatással foglalkozó hívóközpontot nyit a választópolgárok kiszolgálására (néhány angol helyhatóság területén már müködnek ilyenek). Bár a skóciai hívókőzpontok döntő többségének piaca az Egyesült Királyság, az 52 válaszadóból 16 nyilatkozott úgy, hogy idegen nyelvủ szolgáltatásokat is kínálnak.

Glasgow a Brit-szigetek egyik legfrekventáltabb hívóközpont-telephelye (a hívóközpontokat tömörítő szakmai szervezet, a Call Centre Association központja is itt található). A kőzhiedelemmel ellentétben ennek semmi köze sincs a „kellemes skót akcentushoz”, olyan tényezök állnak mögötte, mint a pénzügyileg vonzó és müszakilag megfelelően felszerelt irodahelységek, illetve a rendelkezésre álló megfelelő munkaerő és a munkaadók és munkavállalók közötti jó kapcsolat.

A skóciai hívóközpontok müködési költségeinek mintegy kétharmadát a munkaerővel kapcsolatos kiadások teszik ki. Egy 39 brit és ír hívóközpontot érintő felmérés adatai szerint Glasgow a második legrosszabbul fizetö hívóközpont-telephely (a bejövő hívásokat fogadó alkalmazottak átlagfizetése évi 8900 angol font a glasgow-i hívóközpontokban, míg ugyanez a szám Leeds-ben 10 000, Newcastle/Sunderland területén 10 025, Dublinban 10 900, a legjobban fizető Slough-ba pedig 13300 angol font (Bain-Taylor 1999). A kimenő hívásokat kezdeményező alkalmazottak esetében sem sokkal jobb a helyzet, Glasgow e tekintetben hátulról a nyolcadik helyen áll.

Sok kritika éri a skót sajtó részéről a regionális bérkülönbségeket, elsősorban azokat a vállalatokat támadják, amelyek ugyanazért a munkáért eltérő fizetést adnak a különböző régiókban mủködő hívóközpontjaikban. Amint egyre több régió éri el azt a kritikus tömeget, amellyel a hívóközpontok számára vonzó telephellyé válhat, az e tekintetben korábban sikeres területek (köztük Skócia) előnye hamar megszünhet.

\section{Összefoglalás}

A tanulmány egy egyre jelentősebb szolgáltatási ágazat, a hívóközpontok kialakulásának okait, az azt lehetővé tevő tényezőket és az ágazat eddigi fejlődését vizsgálja, kitérve a hívóközpontok lehetséges jövőbeli fejlődési esélyeire is. A hívóközpontok elsősorban az új kommunikációs technológiáknak köszönhetik sikerüket, amelyek lehetővé teszik, hogy bizonyos, általában nem stratégiai fontosságú, hanem rutinjellegü és szabványosítható szolgáltatásokat a vállalatok korábbi telephelyeikröl előnyösebb (leginkább olcsóbb) telephelyekre, hátsó irodákba helyezzenek át. Elvileg ezek a központok bárhová telepíthetők, ahol megfelelö távközlési infrastruktúra és munkaerő áll rendelkezésre, így a periférikus területek számára új lehetỏséget biztosítanak a gazdasági vérkeringésbe való bekapcsolódásra. A tanulmány azt is vizsgálja, hogy a hívóközpontok eddigi telephelyi döntéseik során a regionális kiegyenlítődés irányába hatnak-e, avagy az erősebb gazdasági alappal rendelkező 
régiókba települnek-e, a már meglévő fejlettségbeli különbségeket erősítve. Az eddigi fejlemények mindenképpen a regionális koncentrációt, a gazdasági térben már korábban is központi helyzetben lévő régiók további funkcionális megerősödését és térnyerését mutatják: Írország összes hívóközpontjának kilenctizede a dublini régióban, az angol hívóközpontok több mint egynegyede a Londonnal együtt számított délkeleti régióban található, de a földrajzilag periférikus területek (például Skócia) esetében is a regionális központok azok, amelyek a hívóközpontok első számú telephelyei. Ugyanakkor tudatos helyi és regionális politikával számos területnek van esélye hívóközpontok letelepítésére (ezt bizonyítja például az északkeletangliai hívóközpontok magas száma az ottani üzleti parkokban).

A hívóközpontok telepítő tényezöinek elemzése után az írás megpróbál reális képet nyújtani az ágazat jelenlegi helyzetéről és a gazdaságfejlesztésben játszott szerepéről, kitérve azokra a tényezőkre, amelyek a hívóközpontok fejlesztése mellett szólnak (új munkalehetőségek, fö- és mellékállású munkahelyek teremtése; regionális export növekedése a hívóközpontok tevékenysége révén; a régió ismeretanyagának bővülése a munkaerő folyamatos képzésével; a munkaerö versenyképességének erösödése az új képességek elsajátításával; a „life-long learning”, élethosszig tartó tanulás alapelveinek elfogadtatása a munkaerővel stb.), és azokra a korlátokra is, amelyek miatt megfelelö óvatossággal kezelendőek ezek az új létesítmények (a hívóközpontok tulajdonképpen szolgáltatások iparosított formái, intenzív és rutinszerủ munkával és annak veszélyeivel; nagyfokú specializáció a munkaerő részéről: gyakran kevés képességre van szükség és azok nem mindig konvertálhatók máshol; erös kontroll, munkafolyamatok és a dolgozók felügyelete; a munkafolyamatok részekre bontása és a lapos vállalati szerkezet miatt kicsi a karrierépítés esélye; földrajzilag mobil, kevés helyi kötődéssel rendelkezö tevékenység, könnyen találhat egy még olcsóbb telephelyet; hosszú távon a technológiai fejlődés, például az Internet használatának szélesebb körben történő elterjedése kiszoríthatja a hívóközpontokból az emberi munkaerőt). Mivel igen rövid múlttal rendelkező ágazatról van szó, ma még nehéz elöre látni, hogy hosszabb távon milyen szerepet játszanak a hívóközpontok a regionális gazdaságban, és hogy eszközei lehetnek-e a gyengébb gazdasági teljesítményü területek fejlesztésének, interregionális kapcsolatok kialakításának.

További kutatások kellenek annak a kérdésnek a megválaszolására, hogy Magyarország milyen esélyekkel pályázhat nemzetközi hívóközpontok letelepítésére, illetve a magyar piacot kiszolgáló hívóközpontok vonzására mely magyarországi régióknak vannak a legjobb esélyei. Ami a nemzetközi hívóközpontokat illeti, Magyarországnak véleményünk szerint egyelőre a magyar munkaerő idegen nyelvtudásának színvonala miatt, nincs olyan számottevő versenyelönye, amely révén komoly vetélytársa lehetne például Nagy-Britanniának, Írországnak vagy a skandináv országoknak (ahol vagy anyanyelvként beszélik az üzleti élet szinte kizárólagos világnyelvét, az angolt, vagy a lakosság igen nagy százaléka idegen nyelvként beszél angolul és németül). Arra a kérdésre, hogy a magyarországi hívóközpontokat hová érdemes telepíteni, olyan kutatások és felmérések ismeretében lehet választ 
adni, amelyek a müködő hívóközpontok sajátosságait (regionális eloszlás, telephely-választási kritériumok, ágazat), a helyi munkaerő tulajdonságait (munkaerőpiac nagysága, kor és nemek szerinti megoszlás, képzettség, esetleg idegen nyelvtudás), az ingatlanpiacot (elegendő mennyiségü és nagyságú épület), a távközlési infrastruktúrát, a helyi gazdaság szerkezetét, a gazdaságfejlesztési politikát és ösztönzörendszert térképezik fel. E tanulmány véleményünk szerint problémafelvetésnek tekinthetö, amelyet további vizsgálatoknak kell követnie.

\section{Irodalom}

Bain, P.-Taylor, P. (1999) Call centres in Scotland. An overview. Scottish Low Pay Unit, Glasgow.

Bain, P.-Taylor, P. (2000) Entrapped by the 'electorinc panopticon'? Worker resistance in the call centre. - New Technology, Work and Employment. 1.2-18. o.

Breathnach, P. (2000) Globalisaton, information technology and the emergence of niche transnational cities: the growth of the call centre sector in Dublin. - Geoforum. 31. 477-485. o.

Bristow, G.-Gripaios, P--Munday, M. (2000) Financial and business services and uneven economic development: some Welsh evidence. - Tijdschrift voor Economische en Sociale Geografie. 2. 156-167. o.

Bristow, G.-Munday, M.-Gripaios, P. (2000) Call centre growth and location: corporate strategy and the spatial division of labour. - Environment and Planning A. 519-538. o.

Business, bournemouth.ac.uk weboldal.

Call Centre Association, Glasgow hivatalos honlapja (www.cca.org.uk).

Call Centre Association, Glasgow adatszolgáltatása (e-mail).

Fernie, S.-Metcalf, D. (1998) (Not) Hanging on the Telephone: Payments Ssytems in the New Sweatshops. Centre for Economic Performance, London School of Economics.

GIPA (1997) Call Centres Review. Grimleys International Property Advisers. 25 Bucklesbury, London EC4N 8DA.

Grimes, S. (1999) Ireland's information society - a late developer catches the wave. - North (The Journal of Nordregio). December. 21-26. 0.

Hoogvelt, A., (1997) Globalisation and the Postcolonial World. Macmillan, London.

IDS (1997) Pay and Conditions in Call Centres. report 739/June. Income Data Services. 193 St John Street, London.

Knox, P.L. (1995) World Cities in a World System. - Knox, P.L.-Taylor, P.J. (eds.) World Cities in a World System. Cambridge University Press, Cambridge. 3-20. o.

Mitial (1997a) European Call Centre Directory. The Mitial Group. 3rd Floor, Redwither Tower, Redwither Business Park, Wrexham LL13 9XT.

Mitial (1997b) Telephone Call Centres in the British Isles: 1996/7. - Location Research Monitor. Mitial Industrial Market Research, Wrexham.

Richardson, R. (1994) Back-officing front office functions - organisational and locational implications of new telemediated services. - Mansell, R. (ed,) The Management of Information and Telecommunication Technologies. ASLIB, London. 309-335. o.

Richardson, R. -Gillespie, G. (1996) Advanced communications and employment creation in rural and peripheral regions. The Annals of Regional Science 30, 91-110. o.

Richardson, R.-Marshall, N. (1996) The growth of telephone call centres in peripheral areas of Britain: evidence from Tyne and Wear. - Area. 3. 308-317. o,

Richardson, R.-Belt, V.-Marshall, N. (2000) Taking calls to Newcastle: the regional implications of the growth in call centres. - Regional Studies, 4. 357-369, o.

Winnett, C.-Stillwell, J.-Leigh, C. (1997) Az innováció tervezése Yorkshire-Humberside régióban. Horváth Gy. (szerk.) Régiók felemelkedése és hanyatlása. Regionális átalakulás a Brit-szigeteken. MTA Regionális Kutatások Központja, Pécs. 203-225. o. 